\title{
Strengthening integrated learning: Towards a new era for pluriliteracies and intercultural learning
}

\author{
Fortalecimiento de aprendizaje integrado: \\ hacia una nueva era para pluri-alfabetizaciones \\ y aprendizaje intercultural
}

\author{
Do COYLE \\ University of Aberdeen, Aberdeen, Scotland, UK \\ do.coyle@abdn.ac.uk
}

\begin{abstract}
The expansion of Content and Language Integrated Learning (CLIL) on a global scale has brought to the fore challenges of how alternative, more holistic approaches to learning might transform classrooms into language-rich transcultural environments. Integrated approaches can offer learners opportunities to engage in meaning-making and language progression through cognitively challenging and culturally-embedded sequenced activities, as reflected in the 4Cs Framework (Content, Cognition, Communication, and Culture). These emphasise classroom language as well as learners' needs to access the variety of language that helps them learn an additional language effectively-as represented in the Language Triptych. However, it is well documented that complex contextual variables make it difficult to realise CLIL's potential. Recent research by the Graz Group into how to better integrate the 4Cs' components has led to development of the Pluriliteracies Framework, in which conceptualization and communication come together and learners are encouraged to language (or articulate) their learning in their own words. This demands new ways of conceptualizing, planning, and sequencing activities that support learners in accessing new knowledge whilst developing existing and new language skills must be shared and understood by teachers. The Pluriliteracies model is evolving, and there is a clear need for further work.
\end{abstract}

Key words: language-driven CLIL; didactic transposition; lesson plans; language skills; language teacher education.

\section{Resumen}

La expansión de Aprendizaje Integrado de Contenidos y Lenguas Extranjeras (AICLE) en una escala global ha traído delanteros los desafíos de como los enfoques alternativos y más integrales podrían transformar las aulas en entornos transculturales ricos en lenguaje. Los enfoques integrados pueden ofrecer los alumnos oportunidades para participar en la creación de la significancia y la progresión de la lengua por medio de actividades secuenciadas cognitivamente desafiantes y culturalmente empotrados, como se refleja en el Marco de los 4C (Contenido, Cognición, Comunicación y Cultura). Estos enfatizan lenguaje del aula, así como las necesidades de los alumnos para acceder a la variedad de lenguaje que les ayuda a aprender un idioma adicional con eficacia, como se representa en el Tríptico de Lenguaje. Sin embargo, está bien documentado que las variables contextuales complejas hacen difícil realizar el potencial de AICLE. Investigaciones recientes realizadas por el Grupo de Graz en la manera de integrar mejor los componentes de las 4Cs ha llevado al desarrollo del Marco de Pluriliteracidades, en el que la conceptualización y la comunicación se unen y se anima a los alumnos a lenguar (o articular) su aprendizaje en sus propias palabras. Esto exige nuevas formas de actividades de conceptualización, planificación, y secuenciación que soportan los alumnos en el acceso a nuevos conocimientos mientras que desarrollan existentes y nuevas habilidades lingüísticas deben ser compartidos y comprendidos por los maestros. El modelo del Pluriliteracidades está evolucionando, y hay una clara necesidad de seguir trabajando.

Palabras claves: AICLE impulsado por lenguaje; transposición didáctica; planes de lecciones; habilidades lingüísticas; la formación del profesorado de idiomas.

Received: 2015-02-22 / Sent for peer review: 2015-02-22 / Accepted by peers: 2014-04-24 / Approved: 2015-05-02

To reference this article / Para citar este artículo

Coyle, D. (2015). Strengthening integrated learning: Towards a new era for pluriliteracies and intercultural learning. Latin American Journal of Content and Language Integrated Learning, 8(2), 84-103, doi:10.5294/laclil.2015.8.2.2 


\section{CONTEXT AND CHALLENGES}

There have been great advances in a relatively short period of time in terms of creating a dynamic theoretical and practice-oriented foundation for the development of Content and Language Integrated Learning (CLIL) across Europe and increasingly on a global scale. Changing paradigms in educational contexts - often, but not exclusively, based on rapid technological advancement-are leading to unprecedented changes in how our education systems are evolving and how the complex processes involved in learning are being acted out in classrooms. Increasingly, moves towards ensuring our young people in formal schooling are skilled in knowledge construction and meaning-making in order to equip them for an uncertain future, are debated and experimented at length. Fullan and Langworthy (2014) conceptualise a case made for 'new pedagogies' where:

Teaching shifts from focusing on covering all required content to focusing on the learning process, developing students' ability to lead their own learning and to do things their learning. (p. 17)

It is against this dynamic backdrop where learning and learners are prioritised that approaches to more integrated language curriculum - where meaning-making connected to deepening content learning is also transparently connected to language progression - are rapidly increasing across the world. Content and Language Integrate Learning is one such approach where, according to Dalton-Puffer (2007):

\footnotetext{
Curricula of so-called subjects (e.g. geography, history, business studies) constitute a reservoir of concepts, topics and meanings which can become the object of 'real communication' where natural use of the target language is possible. (p. 3)
}

CLIL started to gain momentum in the 1990s within the European context as a move towards profiting from inherent multilingualism across nations and ensuring that those linguistically and culturally-rich environments for learning are fully utilised and exploited (Lasagabaster 
and Sierra, 2010). It is well documented (Marsh, 2002; Eurydice, 2006; Coyle and Beardsmore, 2007; see also the overview by Ruiz de Zarobe, 2013) that we are now entering a new era which brings together multiple aspects of learning within which language learning must also be situated into a more coherent whole. This demands 'new thinking' in terms of pedagogy and classroom practices if CLIL is to become genuinely embedded into the regular curriculum anywhere in the world (Meyer et al., 2015).

In 2010, Coyle, Hood, and Marsh published the Cambridge University Press book CLIL, which has the following definition:

Content and language integrated learning is a dual-focussed educational approach in which an additional language is used for learning and teaching of both content and language. That is, in that teaching and learning processes, there is a focus not only on language and not only on language. (p. 1)

This definition alongside many other similar ones emphasises the need to integrate content learning with subject learning with an emphasis on raising awareness of and developing the required skills to successfully learn and teach in these classes. It echoes the Council of Europe's ideal (in the Languages of Schooling, 2010; see Figure 1) of a more holistic view of the languages of schooling, connecting the using and learning of foreign languages, heritage languages, and second languages illustrated by Orban's (2008, cited in Coyle, 2009) statement that 'we need to have two or more languages in order to know we have one ...'

As the founding principle of developing a CLIL approach lies in its flexibility to respond to specific contexts for learning, it soon became apparent that for CLIL to be effective it had to be contextembedded and content-driven yet with specifically-determined target language outcomes. Building on the premise that language is our greatest learning tool, CLIL seeks to connect learners to the realities of using different languages at different times for different purposes. 
Figure 1. Languages of schooling.

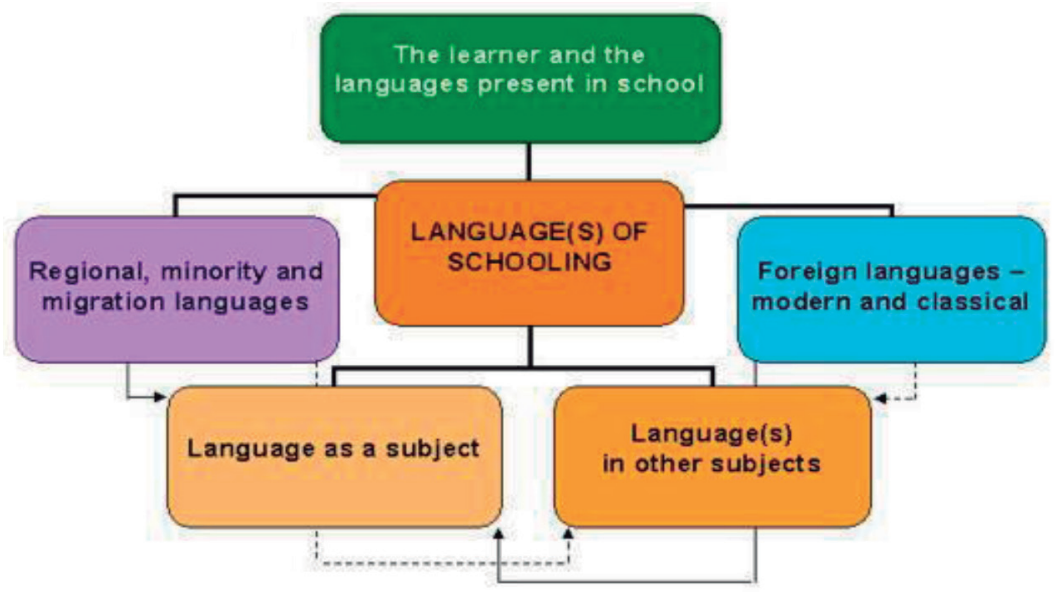

This position led to experimentation with different models for CLIL. As Hugo Baetens-Beardsmore (1992) famously stated, "there is no universally applicable theory of bilingual education and no given model, no matter how successful, is for export" (p. 274).

As CLIL programmes flourished there was increasing flexibility of length of programmes, language(s) targeted, the age and linguistic proficiency of the learners as well as the subject matter and content. Increasingly questions were being debated about the nature of CLIL the list is extensive, but some prominent concerns follow:

- Is a programme more content-oriented than language-oriented or somewhere in between? What are the implications?

- Is it a top-down approach to learning or a bottom-up? What does this mean for us?

- What is 'content' if you are a language teacher?

- What is 'language' if you a subject teacher?

- Where does integration fit in? Cross-curricular themes rather than a defined discipline such as History?

- Where are the resources?

- As a teacher new to CLIL how do I know how to plan, monitor and assess teaching and learning? 
If the overarching goal of our teaching and learning is to envision future global citizens to communicate and learn effectively in more than one language, then it becomes increasingly clear that fundamental changes to classroom practices - based on a changing mind-set and understanding by teachers - is needed. I shall illustrate this point with a quotation I regularly use:

Too much attention is directed towards finding the 'best method; even though fifty years of educational research has not been able to support such generalisations. Instead, we should ask which methods or combination of methods is best for which goals, which students and under which conditions. (Dahllof, 1991, p. 148)

The conditions alluded to and the spaces which constitute them, however, are rapidly requiring those who work and learn in them to become increasingly plurilingual — defined in the Common European Framework of Reference for Languages (Council of Europe, 2000) as an individual's ability to 'use several languages to varying degrees and for distinct purposes' (p. 168) across several cultures. Garcia (2009) supports this in her reference to valuing plurilingualism because it extends mastery of two or more standard languages to include hybrid language practices' (p. 55).

The need to focus attention on the developing learners' plurilingual and pluricultural competences leads Stigler and Hiebert (1999) to remind us:

If you want to improve the quality of teaching, the most effective place to do so is in the context of a classroom lesson .... The challenge now becomes that of identifying the kinds of changes that will improve learning for all students ... of sharing that knowledge with other teachers. (p. 131)

It is the emphasis on changes to classroom practices, the underlying pedagogic principles used to guide learning and teaching and the shared ownership of a vision for those evolving practices that are our greatest challenges. Unravelling the principles underlying changes to pedagogic practices required for successful CLIL will now be considered. 


\section{METHOD}

The 4Cs Conceptual Framework was developed in the 1990s by Coyle et al. (2010) working with a range of CLIL teachers in a range of contexts in order to provide a guide for emphasising the fundamental elements of CLIL (Coyle, 2002, 2007, 2010; Llinares et al., 2010). It was a means of enabling both language teachers and subject teachers to be supported in a basic understanding that CLIL was not about deciding which content or which language needed to be taught but involved a much deeper and complex conceptualisation of learning including cognitive demands and intercultural understanding.

Figure 2. 4Cs conceptual framework.

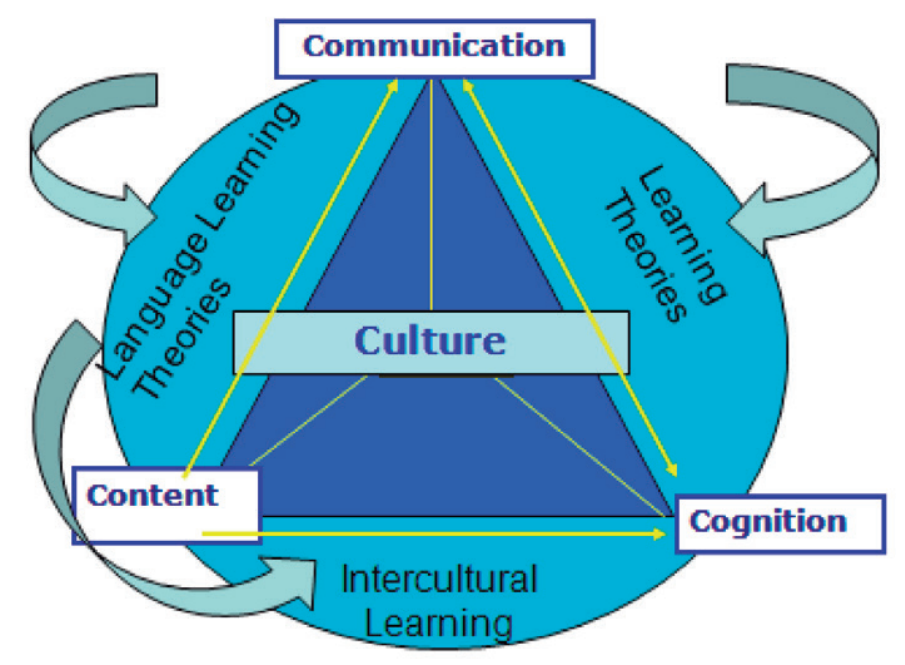

The visualisation of the 4Cs (see Figure 2) identifies key components of CLIL set within the context in which it is played out as: content, cognition, communication and culture.

Content refers to the subject or theme of the learning in any curriculum which ranges from subject disciplines such as Science, History and Geography to cross disciplinary themes such as global citizenship, sustainability, or community development. It involves curricular knowledge and understanding. 
However, content cannot be considered in isolation but as part any learners' cognitive development and intercultural understanding. Cognition or cognitive development in this sense relates to the cognitive level of the learning - one of the clearest examples being the level of thinking that CLIL tasks demand in relation to the content. This can be illustrated by using Anderson and Krathwohl's (2001, pp. 678) revised version of Bloom's Taxonomy (1956) to plan how tasks which target the development of content understanding involve developing learners' higher thinking and problem solving skills. Rooted in social constructivist principles of learning, deep learning involves social settings where learners are enabled to articulate their learning before internalising their own interpretation of these concepts on an individual basis. These processes are fundamental to meaning-making - a case of How do I know what I know 'til I hear what I say? Planning for higher-order thinking and deep learning has not traditionally been in the repertoire of language teachers who have drawn extensively on Second Language Acquisition theories for language learning for decades. Whilst subject teachers may be familiar with concept formation and problem-solving, the way in which these link to language are less likely to be part of planning. The dilemma is exacerbated by the challenge that for many CLIL learners their linguistic level in the CLIL vehicular language is likely to be lower than their cognitive 'learning' level. Yet as a core principle in CLIL classrooms, the cognitive level at which learners operate in L1 cannot be compromised.

This leads us on to Communication since it is language that cements meaning-making and understanding (cognition) of the subject matter (content knowledge) with the language used to learn, to communicate and to externalise and internalise understanding. Communication is the language that is used to construct knowledge, used for meta-cognitive and communicative purposes as well as reflective intervention (Bruner, 1982) on learning. Perhaps it is helpful to emphasise the difference between language using and language learning since both are required in the CLIL classroom. Language teachers 
are familiar with language learning often based on grammatical progression and communicative development. However, I would argue that in general neither language teachers nor subject teachers are familiar with the need to consider the role of language using for learning; that is, when the language is both the medium and the message. Grammatical chronology does not provide the wealth of language required for CLIL learners to access the discourse integral to the learning Science or History when it is needed. Disciplines have their own discourse patterns (academic literacies), which are specific to that discipline as well as a requirement that meta-cognition or learning how to learn also relies on linguistic functions not in the usual experiences of the school -based language lesson. Teachers, therefore, are faced with the need to reconceptualise practices if in CLIL settings language is considered both a learning tool and a communication tool.

The Language Triptych (Coyle et al., 2010) as shown in Figure 3 , goes some way to drawing attention to this dilemma by bringing together 'content-obligatory', 'content-compatible', and 'contentenriching' language into a visual which focuses attention on identifying the language needed for learning as follows:

- language of learning: content-obligatory language; that is, the key phrases, expressions, lexis, and content specific language.

- language for learning: content-compatible language, which focuses on all the language required for enabling learning to happen in class; for example, task-specific language (such as that required to work in a group).

- language through learning: content-enriching language, which is the language linked to deeper conceptual understanding on an individual level (that learners need to articulate in order to reiterate their own learning).

The fourth ' $\mathrm{C}$ ' connects cultural and intercultural understanding to learning in contexts where more than one language is being used. 'Culture' is a complex phenomenon open to wide interpretation (Eagleton, 2000). 
Figure 3. The Language Tryptych

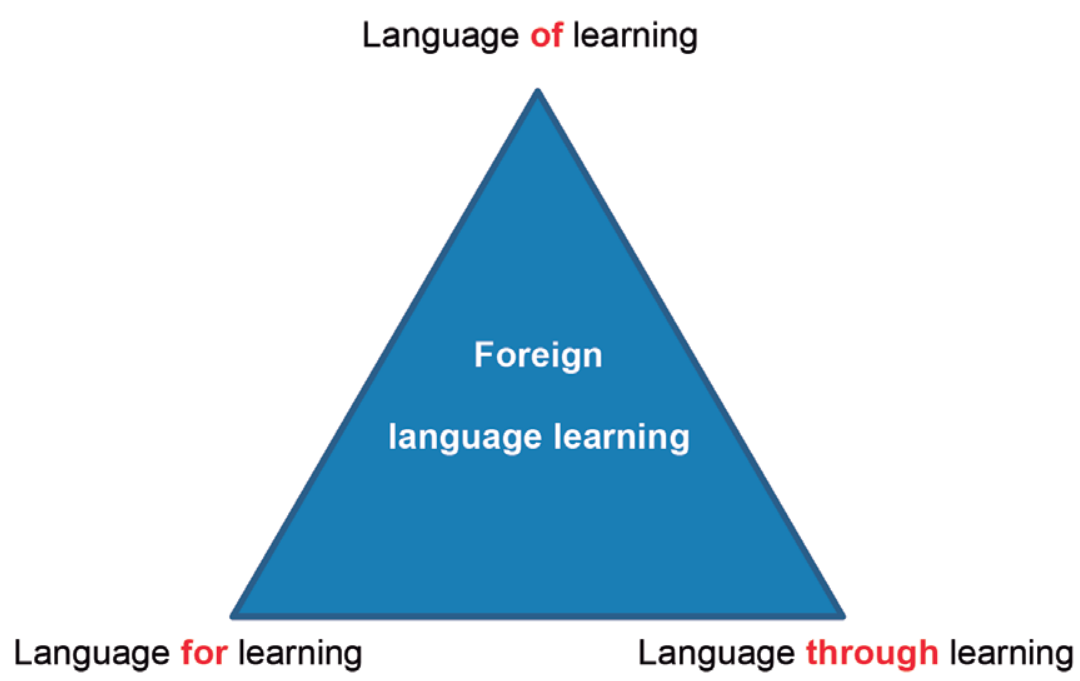

Moreover, building on previous arguments, developing plurilingual competence in learners will also involve raising pluricultural awareness in order to enable individuals to work, learn and communicate successfully. In the European Centre for Modern Languages (ECML) publication Plurilingual and Pluricultural Awareness in Language Teacher Education: A Training Kit, edited by Bernaus et al. (2007), these competences lie at the core of twenty-first century learning:

Cultural patterns, customs, and ways of life are expressed in language: culture-specific world views are reflected in language .... (L)anguage and culture interact so that world views among cultures differ and that language used to express that world view may be relative and specific to that view. (Brown, 1980, p. 138)

Moreover, building on previous arguments, developing plurilingual competence in learners will also involve raising pluricultural awareness in order to enable individuals to work, learn and communicate successfully. In the European Centre for Modern Languages (ECML) publication Plurilingual and Pluricultural Awareness in Language Teacher Education: A Training Kit, edited by Bernaus et al. (2007), these competences lie at the core of twenty-first century learning: 
Plurilingual and pluricultural competence is not achieved by overlapping or juxtaposing different competences; rather it constitutes a global and complex competence of which the speaker can avail himself or herself in situations characterised by plurality. (p. 17)

However, in CLIL contexts there is not only a sense of broader societal cultures that are inextricably connected to language use, but in addition the academic culture associated with individual subjects or disciplines. Hence the focus is also on the role of culture in learning. Within the paradigm of socio-cultural theory, culture underpins both language and cognition since it is through 'languaging' or 'putting into our own words' individual thinking that learners develop conceptual understanding. This in turn is embedded in the cultural context of learning and the ways in which particular disciplines use language. In other words, language is part of an individual's 'linguistic DNA' that is context-related and culturally mediated.

Hence, the 4Cs Framework provides a means of guiding the foundations for learning, which conceptually go beyond a simplistic emphasis on the language and content of learning, and draws upon the need to develop greater intercultural awareness and academic reading and writing skills as learners progress.

\section{A PARADIGM SHIFT FOR INTEGRATED LEARNING}

Over the years, whilst clearer guiding principles have emerged relating to CLIL classroom practices substantiated by a variety of research studies - both supporting CLIL and raising concerns — an increasing awareness of the need to understand better the nature of integrated learning brings into question the 'how' (see for example Coyle, 2011; Dalton-Puffer, 2007). Increasingly, questions are raised about the effectiveness of CLIL and the quality of the pupils' classroom learning. The shifting sands of the learning agenda, from knowledge transmission to meaning-making whilst using more than one language, are increasingly being brought under the microscope. Moreover, it can be argued that whilst the 4Cs Framework guides the what of CLIL it 
does not provide the how (of integration) (see for example Llinares et al. 2010; Meyer et al., 2015). The following questions are raised:

- Content: What is content knowledge? Who owns it? How is it shared? What are the differences between meaning-making and knowledge transfer?

- Cognition: Can progression in meaning-making using cognitive, social, and linguistic resources be separated from content and language use?

- Communication: How can we support language learning and using in a CLIL context where language mediates and structures learning in culturally determined ways?

- Culture: How can using a broader societal and academic subject lens that puts cultural and intercultural references at the core be made more explicit and supported further?

Fundamental questions such as these require a paradigm shift-one where interconnectedness is at the core and where there is a shared understanding of integrated learning. The Graz Group (2014), a team of CLIL researchers funded by the European Centre for Modern Languages (Council of Europe), ${ }^{1}$ is currently tasked with reframing integrated approaches through a new dynamic model (Meyer et al., 2015). This brings together two crucial processes: learner progression in knowledge construction and meaning-making; while language using and development make these happen.

However, changing the pedagogic focus brings into question debates that have dominated the CLIL agenda for several decades. These essentially are to do with the role and nature of language in integrated learning such as redefining the place of grammar, the conflict between a focus on meaning and a focus on form, and the role of language error correction. Mohan and Beckett (2003) take a hard line:

We are not aware of any evidence or explicit and detailed claims that the correction of errors of grammatical form is a sufficient

1 See the Web site at http://www.ecml.at/F7/tabid/969/Default.aspx. 
condition for the development of oral and written language as a medium of learning. (p. 423)

However, Van Lier (1996) usefully suggests that:

We should not let ourselves be trapped inside a dichotomy between focus on form and a focus on meaning but rather a focus on language ... in practice it becomes impossible to separate out form and function neatly in the interactional work that is being carried out. (p. 203)

Yet if concept development and knowledge construction are at the core of CLIL, these require different kinds of language that do not depend only on grammatical knowledge and understanding which underpin much of the tradition of language learning. Moreover, the type of language required involves an awareness and understanding of the academic discourses that drive them. This is also referred to as academic literacies. Yet in subject or content learning, the development of academic literacy skills is not usually made transparent in more subject-oriented classes - especially in the foreign or second language. It would seem, therefore, that conceptual progression and the language used to enable that to happen are rooted in neither the traditions of language learning nor subject learning and hence are rarely explicitly taught at any level or context. Vollmer's (2008) work into the development of academic language with both L 1 and L 2 learners in CLIL settings corroborates this view.

Both groups of learners show considerable deficits in their academic language use...the specific competences in handling the language dimensions adequately and in expressing their thoughts and findings appropriately or functionally according to the genre(s) demanded are equally low, they show a serious lack of command over a sensitivity for the requirements of academic language use, both in L2 and in L1. (p. 272)

The need to shift the pedagogic paradigm in which CLIL is situated emerges as a priority, as Wolfe and Alexander (2008) summarise: "Argumen- 
tation and dialogue are not alternative patterns of communication; they are principled approaches to pedagogy" (p. 15).

\section{AN EVOLVING PLURILITERACIES APPROACH}

According to Bonnet (2012), a deeper understanding of how effective integration of content learning and language learning can be conceptualised is starting to emerge. For example, the Graz Group (see previous reference) has chosen an alternative lens through which to explore integrated learning. With a particular focus on the development of academic literacies to support progression in conceptual understanding, academic discourse is used as a filter for cultural and intercultural learning that draws on literacy development. Literacy, in this sense, can be defined as 'control of "secondary discourses"' (Gee, 1989, p. 542) and across languages is the ability to 'think about and analyse texts critically, master sophisticated language and convey appropriate content and recognise how meanings are made within a wide range of texts ... and discourse communities' (Crane, 2002, p. 67).

However, when literacy development transcends languages then a pluriliteracies approach begins to take shape:

A pluriliteracies approach focuses on developing literacies for purposeful and appropriate meaning-making in subject disciplines/ thematic studies across languages and cultures. It is predicated on the principle, that the primary evidence of learning is language (Mohan) which in turn mediates and structures knowledge in culturally determined ways. (The Graz Group, 2014)

By putting plurliteracies at the heart of our approach to learning, there is a focus not only on enabling and empowering the learner to purposefully communicate across languages and cultures (academic as well as social) but also on promoting the essential role of language in shaping students' thinking and learning. From this perspective, integration consists of two inter-related continua: conceptual development and language development (see Figure 4). Conceptual development 
draws on work by Polias (2007, p. 46) and Veel (1997) where four major activity domains are identified to demonstrate progression in learner knowledge construction. For example, if learners are working on scientific concepts, the four progressive domains are as follows: doing science (procedure, procedure recount); organising science (descriptive and taxonomic report); explaining science (sequential, causal, theoretical, factorial, and consequential and exploration); arguing/challenging science (exposition, discussion). Each of these progressive domains is built on the principle that progression will demand not only will increasing cognitive demands but also linguistic and culturally embedded language in order to move along the communicating continuum.

Drawing on the work of Halliday (Halliday and Mathiessen, 2004), a Systemic Functional Linguistic framework helps to identify the kind of interpersonal language needed to articulate learning in different academic settings - such as Science or History; that is, the use of language to carry out 'understand and express attitudes towards the academic content' (Llinares, Morton, \&Whittaker, 2012, p. 220). Progressing along the conceptual continuum, as illustrated in Figure 4, involves language which connects to developing the language or genre referred to above in the four domains, the mode which learners are required to use (for example, speaking, writing, and image), the style required (for example, formal/informal) and the purpose. From this perspective, the communication continuum provides a language model for how form (language) and meaning (content) are inter-related complex resources rather than seeing language progression as a transition from errors to correct form.

This theoretical model (see Figure 4) focuses on the spaces that are created at the intersection of the two continua. These spaces progress from novice or beginner to intermediate and expert.

The pluriliteracies model therefore is built on the following tenet: 
Figure 4. The Graz Group pluriliteracies model (2014).

\section{Mapping Pluriliteracies Development}

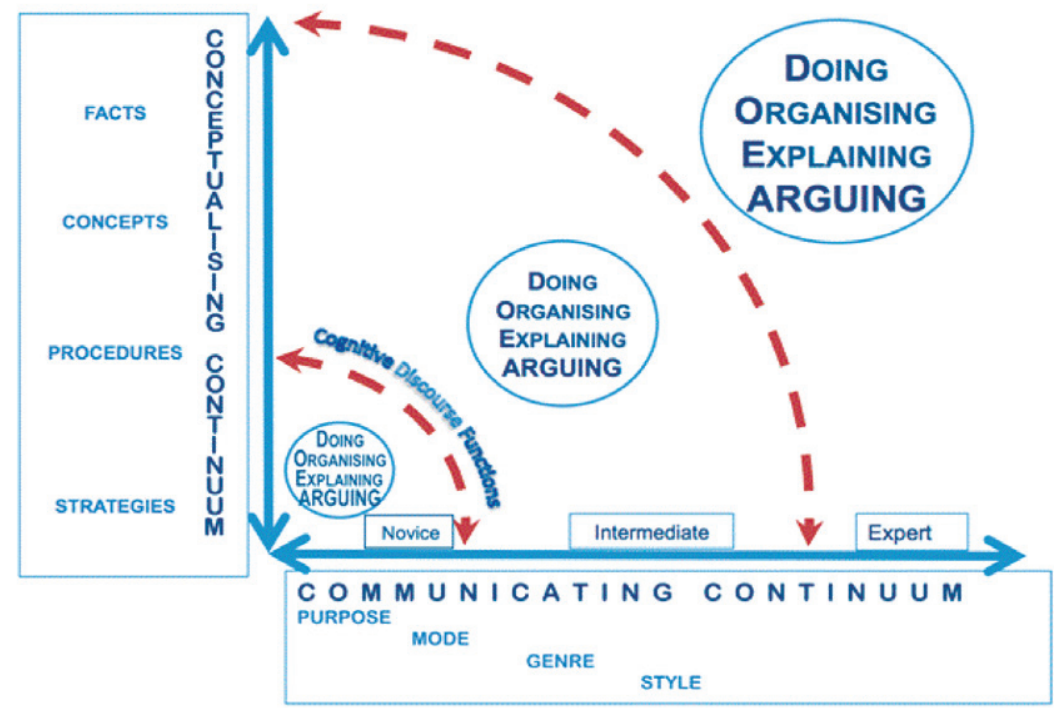

If the ability to successfully navigate multimodal representations of knowledge is indeed fundamental to the process of meaning-making and knowledge construction and thus to the acquisition of subject-specific literacies required to progress along the knowledge pathway. (Meyer et al., 2015)

This approach challenges the dominate language learning model based on grammatical chronology and instead takes an alternative pathway for identifying the kind of language which learners will need in their CLIL context. However, this does not mean that grammar has no role to play, but that grammar is no longer the filter through which language is selected for learning. This model is evolving and being developed and experimented by teachers and their learners in diverse contexts. Interestingly, findings so far indicate that approaches involving literacies impacts on the learners' first as well as additional languages, thus reinforcing the principle that CLIL teaching is 'good teaching' impacting across the curriculum. 
The challenge for us all as CLIL teachers, teacher educators, researchers and learners is to develop together pedagogic approaches that integrate content and language in ways that lead to independent successful learners able to be pluriliterate citizens in tomorrow's world. A quotation from Fullan and Langworthy (2014) opened this article and similarly will draw it to a reflective and challenging conclusion. This article suggests that CLIL has a genuine contribution to make.

\begin{abstract}
Our schools and our pedagogies need to inspire and to ensure that all students are capable of independent learning and purposeful action in the world, and have not only the foundation but also the practical experiences and technical skills to create valuable futures for themselves and their societies. (p. 78).
\end{abstract}

\title{
ACKNOWLEDGEMENTS
}

This paper is based on the Opening Address presented at the 5th Biennial CLIL Symposium: New trends, challenges, and opportunities in the CLIL classroom, Universidad de La Sabana, Chía, Colombia, 12 September 2014.

\section{REFERENCES}

Anderson, L. W., \& Krathwohl, D. R. (Eds.). (2001). A taxonomy for learning, teaching and assessing: A revision of Bloom's taxonomy of educational objectives. New York, NY: Longman.

Baetens Beardsmore, H. (1992). Bilingual education. In J. M. Lynch, C. Modgil, \& Sohan Modgil (Eds.), Cultural diversity and the schools: Vol. 1. Education for cultural diversity: Convergence and divergence (pp. 273-283). London, England: Falmer Press.

Bernaus, M., Andrade, A. I., Kervran, M., Murkowska, A., \& Sáez, F.T. (2007). Plurilingual and pluricultural awareness in language teacher education: A training kit. Retrieved from the Council of Europe, European Centre for Modern Languages website: http:/ /archive. ecml.at/mtp2/publications/B2_LEA_E_internet.pdf 
Bloom, B. S., Engelhart, M. D., Furst, E. J., Hill, W. H., \& Krathwohl, D. R. (1956). Taxonomy of educational objectives: The classification of educational goals, Handbook I: Cognitive Domain. London, England: Longmans.

Bonnet, A. (2012). Language, content and interaction: How to make CLIL classrooms work. In D. Marsh \& O. Meyer (Eds.). Quality interfaces: Examining evidence and exploring solutions in CLIL (pp. 175-190). Eichstätt, Germany: Eichstaett Academic Press.

Bruner, J. (1982). The language of education. Social Research, 49(4), $835-853$.

Crane, C. (2002, November 23). Genre analysis: A step toward understanding the different stages of advanced language instruction. Paper presented at the ACTFL/AATG conference, Salt Lake City, UT. Retrieved from http:// data.georgetown.edu/departments/ german/programs/curriculum/manuscripts/cranegenre.html

Council of Europe (2010). The languages of schooling. Retrieved from the Council of Europe website: http://www.coe.int/t/dg4/ linguistic/Schoollang_EN.asp

Coyle, D. (2002). From little acorns. In D. So \& G. Jones (Eds.), Education and society in plurilingual contexts (37-55). Brussels, Belgium: Brussels University Press.

Coyle, D. (2007). Content and language integrated learning: Towards a connected research agenda for CLIL pedagogies. International Journal of Bilingual Education and Bilingualism, 10(5), 543-562. http://dx.doi.org/10.2167/beb459.0

Coyle, D. (2009, February 27). CLIL for the new curriculum. Paper presented at CLIL conference, Willink Specialist Language College, Reading, UK.

Coyle, D. (2010). Language pedagogies revisited: Alternative approaches for integrating language learning, language using and intercultural understanding. In J. Miller, A. Kostogriz, \& M. Gearon (Eds). Culturally and linguistically diverse classrooms: 
New Dilemmas for teachers (pp. 172-195). Bristol, England: Multilingual Matters.

Coyle, D. (2011). Investigating student gains: Content and language integrated learning. (ITALIC Research Report 09-0670). Retrieved from the University of Aberdeen, ITALIC website: http://www.abdn.ac.uk/italic/documents/ITALIC_Report_Complete_Version.pdf

Coyle, D., \& Baetens Beardsmore, H. (2007). Research on content and language integrated learning (CLIL). International Journal of Bilingual Education and Bilingualism, 10(5), 541-542. http:// dx.doi.org/10.1080/13670050708668197

Coyle, D., Hood, P., \& Marsh, D. (2010). CLIL: Content and language integrated learning. Cambridge, England: Cambridge University Press.

Dahllöf, U. (1991). Towards a new model for the evaluation of teaching. In U. Dahllöf, J. Harris, M. Shattock, A. Staropoli, \& R. Veld (Eds.), Dimensions of Evaluation (pp. 116-152). London, England: Jessica Kingsley.

Dalton-Puffer, C. (2007). Discourse in content and language integrated learning (CLIL) classrooms. Amsterdam, the Netherlands: John Benjamins.

Eagleton, T. (2000). The idea of culture. Oxford, England: Blackwell. Eurydice. (2006). Content and language integrated learning (CLIL) at school in Europe. Retrieved from the Istituto Nazionale di Documentazione, Innovazione e Ricerca Educativa website: http://www.indire.it/lucabas/lkmw_file/eurydice/CLIL EN.pdf

Fullan, M., \& Langworthy, M. (2014). A rich seam: How new pedagogies find deep learning. London, England: Pearson. Retrieved from http://www.michaelfullan.ca/wp-content/ uploads/2014/01/3897.Rich_Seam_web.pdf

Gee, J. P. (1989). What is literacy? Journal of Education, 171(1), pp. $18-25$. 
The Graz Group. (2014). Literacies through content and language integrated learning: Effective learning across subjects and languages. Retrieved from the Council of Europe, European Centre for Modern Languages website: http://www.ecml.at/F7/ tabid/969/language/en-GB/Default.aspx

Halliday, M. A. K., \& Mathiessen, C. M. I. M. (2004). An introduction to systemic functional grammar. London, England: Arnold.

Lasagabaster, D., \& Sierra, J. (2010). Immersion and CLIL in English:

More differences than similarities. English Language Teaching Journal, 64(4), pp. 376-395.

Llinares, A., Morton, T., and Whittaker, R. (2010). The Roles of Languages in CLIL. Cambridge: Cambridge University Press.

Marsh, D. (2002). CLIL/EMILE - The European dimension: Actions, trends and foresight potential (European Commission Report, Public Services Contract DG EAC 3601 Lot 3). Retrieved from the University of Jyväskylä, UniCOM Continuing Education Centre website: http://ec.europa.eu/education/languages/ pdf/doc491_en.pdf

Meyer, O., Coyle, D., Halbach, A., Schuck, K., \& Ting, T. (2015).

A pluriliteracies approach to content and language integrated learning - Mapping learner progressions in knowledge construction and meaning-making. Language, Culture and Curriculum, 28(1), 41-57. http://dx.doi.org/10.1080/07908 318.2014.1000924

Orban, L. (2008, September 26). Address to the EU Language Strategy Conference, Paris, France.

Polias, J. (2007). Assessing learning: a language-based approach. In M. Olofsson (Ed.), Symposium 2006: Bedömning, flerspråkighet och lärande. Stockholm, Sweden: HLS förlag: Nationellt centrum för SFI och svenska som andraspråk.

Ruiz de Zarobe, Y. (2013). CLIL implementation: From policymakers to individual initiatives. International Journal of Bilingual Education and Bilingualism, 16(3), 231-243. http://dx.doi.org/ $10.1080 / 13670050.2013 .777383$ 
Stigler, J.W., \& Hiebert, J. (1999). The teaching gap. New York, NY: Free Press.

Van Lier, L. (2008). Ecological-semiotic perspectives on educational linguistics. In B. Spolsky \& F. M. Hult (Eds.), The handbook of educational linguistics (pp. 596-605). Malden, MA: Blackwell.

Veel, R. (1997). Learning how to mean - scientifically speaking: Apprenticeship into scientific discourse in the secondary school. In F. Christie \& J. R. Martin (Eds.), Genre and institutions: Social processes in the workplace and school (pp. 161-195). London, England: Continuum.

Vollmer, H. J. (2008). Constructing tasks for content and language integrated learning and assessment. In J. Eckerth \& S. Siekmann (Eds.), Task-based language learning and teaching: Theoretical, methodological and pedagogical perspectives (pp. 227-290). Frankfurt-am-Main, Germany:Peter Lang.

Wolfe, S., \& Alexander, R. (2008). Argumentation and dialogic teaching: Alternative pedagogies for a changing world. Retrieved from the Beyond Current Horizons: Technology, Children, Schools, and Families website: http://www.beyondcurrenthorizons.org.uk/ argumentation-and-dialogic-teaching-alternative-pedagogiesfor-a-changing-world/ 